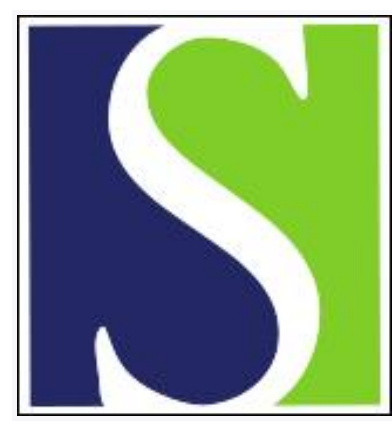

Scand J Work Environ Health 1989;15(3):203-209

https://doi.org/10.5271/sjweh.1861

Issue date: Jun 1989

\title{
Cancer risk in a cohort of licensed pesticide users.
}

by Corrao G, Calleri M, Carle F, Russo R, Bosia S, Piccioni P

Affiliation: Department of Science and Biomedical Technology and Biometrics, University of L'Aquila, Italy.

This article in PubMed: www.ncbi.nlm.nih.gov/pubmed/2781250 


\title{
Cancer risk in a cohort of licensed pesticide users
}

\author{
by Giovanni Corrao, BSc, ${ }^{1}$ Mariella Calleri, BSc, ${ }^{1}$ Flavia Carle, BSc, ${ }^{1}$ Roberto Russo, MD, ${ }^{2}$ \\ Silvano Besia, MD, ${ }^{3}$ Pavilio Piccioni, $\mathrm{MD}^{3}$
}

\begin{abstract}
CORRAO G, CALLERI M, CARLE F, RUSSO R, BOSIA S, PICCIONI P. Cancer risk in a cohort of licensed pesticide users. Scand J Work Environ Health 1989;15:203-209. First admissions to the hospital among 25945 men living in southern Piedmont and holding a license authorizing them to use pesticides were analyzed in a study of the cancer risk related to exposure to pesticides. Standardized incidence ratios significantly higher than one were encountered for malignant skin cancers and lymphomas. The risk of lymphoma was particularly high in predominantly arable areas. The standardized incidence ratios for tumors of the nervous system and hematopoietic tissue showed an interesting age-related pattern and a higher risk in areas primarily devoted to forest tree plantation, but did not reach significance. Certain hypotheses are advanced to explain these findings.
\end{abstract}

Key terms: cohort study, occupational exposure.

Several epidemiologic studies have investigated the relationship between pesticide exposure and the onset of cancer. A review of the literature reveals a complex and far from uniform picture. Blair et al (1) observed that rural populations have a different site distribution of cancer from other population groups. They reported a lower incidence of neoplasms causally associated with cigarette smoking and a higher risk for tumors at other sites, such as stomach, prostate, skin, lymphatic and hematopoietic tissues. A relationship between these tumor sites and chemical compounds used in agriculture has often been suggested $(1-12)$.

Several authors have studied the relationship between exposure to phenoxyacids and chlorophenols and soft tissue sarcomas and lymphomas. However, while numerous reports have supported this hypothesis (13-17), the International Agency for Research on Cancer (IARC) maintains that "case-reports on cutaneous non-Hodgkin's lymphoma and epidemiological results from three case-control studies from one country and from some relatively small cohorts in another country provide limited evidence for the cancerogenicity of phenoxiacids and chlorophenols, but do not allow unequivocal identification of the compounds involved (including those present as impurities in technical-grade compounds [p 50]" (18).

Several authors have suggested that exposure to insecticides such as organochlorine may cause leukemias and aplastic anemias (19), while others did not observe any such connection (20). As a result IARC (18) has stated that "the available data from case reports and from epidemiological studies provide inadequate evi-

\footnotetext{
1 Department of Science and Biomedical Technology and Biometrics, University of L'Aquila, L'Aquila, Italy.

2 Institute of Hygiene, University of Torino, Torino, Italy.

3 Department of Worker Health Protection, Region Piedmont, Asti, Italy.
}

Reprint requests to: Dr R Russo, Istituto di Igiene, Università di Torino, Via Santena 5 bis, I-10126 Torino, Italy. dence to evaluate the carcinogenicity of organic pesticides as a broad class or as individual compounds [ $\mathrm{p}$ 50]."

Furthermore, many studies suggest that there is a relationship between agricultural activities (and sometimes exposure to pesticides) and the onset of cancer of the bladder $(12,21)$, nasal sinus $(5)$, brain $(21,22)$, ovarian mesothelium (23), and lung (24-28).

Thus, while several reports indicate a link between certain pesticides and certain tumor sites, this information is still insufficient, and additional data are needed. Research has to overcome several hurdles in this instance. First, it is not easy to assemble large enough cohorts of agricultural workers. Second, the real exposure history is not easily identified. Third, a matching reference group is difficult to find due to the peculiarities of rural populations.

The area examined in this paper is southern Piedmont (provinces of Asti, Alessandria and Cuneo), where $20 \%$ of the occupationally active men are employed in agriculture and the land is cultivated with crops (30\% arable, $10 \%$ woodland, $20 \%$ pasture and $40 \%$ other crops). Furthermore, in this area, the consumption of chlorophenoxyacetic herbicides was higher than the national average: $0.123 \mathrm{~kg} / \mathrm{ha}$ in $1970 \mathrm{com}$ pared with a national average of $0.060 \mathrm{~kg} / \mathrm{ha}$.

\section{Subjects and methods}

\section{Description of the cohort}

The cohort consisted of 25945 male farmers licensed between 1970 and 1974 to buy and use pesticides denominated by Italian law as toxicologic classes I and II. This period has been chosen because the Italian law on pesticide licenses came into force only in 1970. In that year the Inspectorate of Agriculture received applications for licenses from all farmers who were already using pesticides, and the licenses were issued over 
the next five years. Thus our cohort also included agricultural workers with a previous history of exposure to such products.

\section{Region of the Piedmont Hospital Discharge File}

The Piedmont Hospital Discharge File is a computerized file set up on 1 January 1976 and updated until 31 December 1983. The records are exhaustive, covering all admissions to public hospitals and private clinics in the Piedmont region.

\section{Methods}

The flow chart used for our study is shown in figure 1. The main features are the checking of the diagnoses reported in the discharge files, the transformation of the discharge file to a file of discharged patients, and the calculation of standardized incidence ratio (SIR) values.

\section{Checking the diagnoses in the discharge file}

From the discharge file we extracted reports on all male patients residing in the provinces of Cuneo, Asti, and Alessandria, born before 1952, and diagnosed as suffering from bone, connective tissue or skin tumors [International Classification of Diseases (ICD) 1700-1739]; tumors of the brain or other parts of the nervous system (ICD 1910-1929); lymphatic or hematopoietic tissue tumors (ICD 2000-2099).

Our interest was focused on these diseases in view of the fact that one of our earlier surveys revealed a high incidence of tumors at these sites (29). Using a stratified sampling system (in which each stratum was represented by groups of hospitals homogeneous in size and degree of specialization), we sampled a group of hospitals where we were able to find clinical reports on patients affected by the diseases in question. Two doctors unaware of the purpose of our investigation recoded the original diagnoses, and their recodings were subsequently compared with the original codings listed in the file.

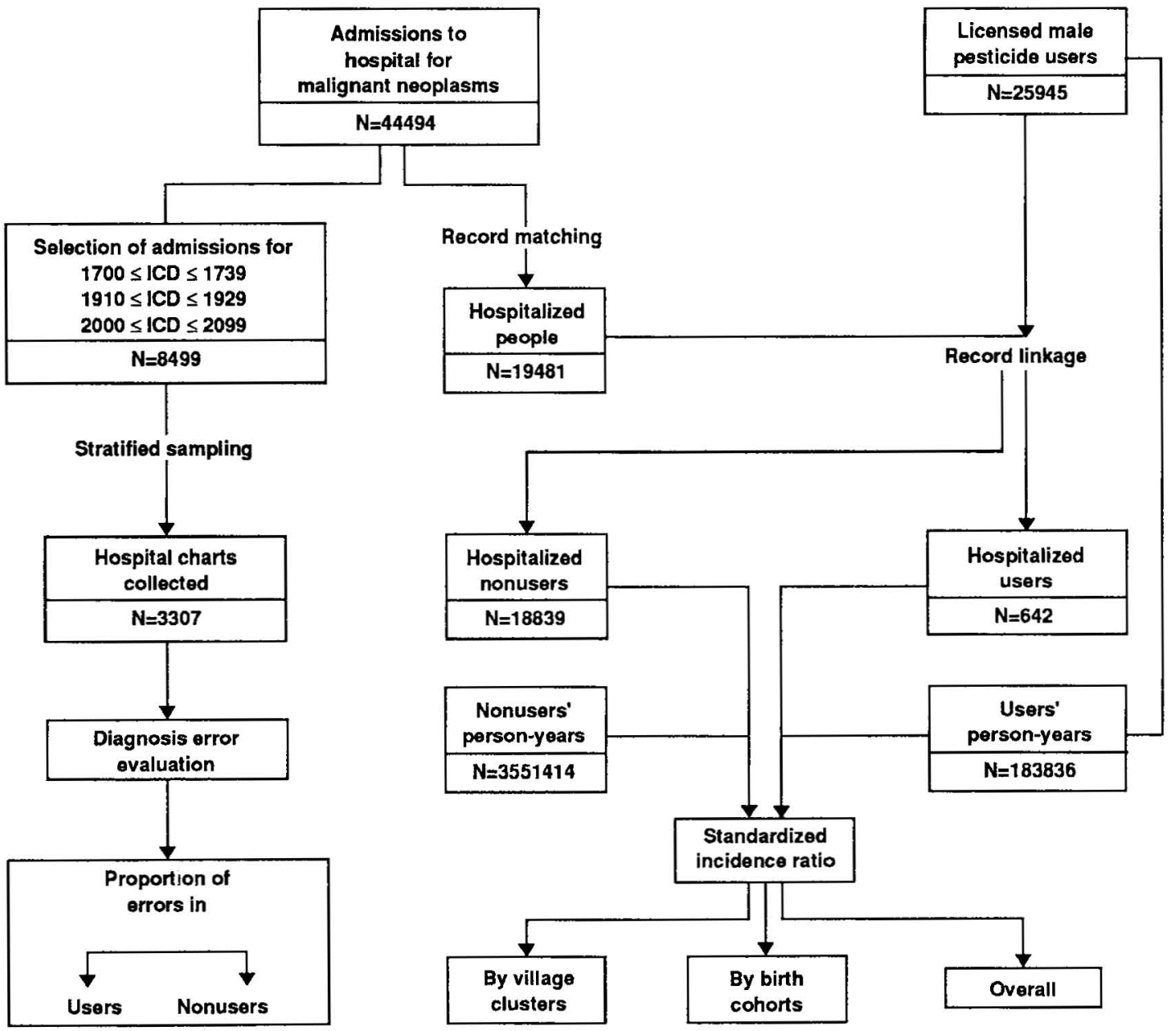

Figure 1. Flow chart of the study. 
This procedure enabled us to calculate the proportion of conflicting diagnoses for each disease and to assess whether the discrepancy was uniformly distributed among the subjects exposed and not exposed to pesticides.

\section{Transformation of the discharge file to a file of patients for the present study}

From the discharge file we extracted all reports on patients admitted between 1976 and 1983 with the tumors in question, the only difference being that in this case we were interested in all malignant tumors that were diagnosed (ICD 1400-2099). We set up an automatic linkage computer program able to recognize multiple admissions for the same patient on the basis of the first three letters of his/her surname, date of birth, and code of place of birth. In this way we were able to transform the discharge files consisting of 44494 records to a patient file consisting of 19494 records.

\section{Calculation of the standardized incidence ratios}

We then matched the patient file to the license-holder file and were able to calculate the numerator of admission rates for the persons in this file and the corresponding value for the unlicensed referents, represented by the number of first admissions occurring between 1976 and 1983. We obtained the denominator of the admission rates for the license-holders by calculating the person-years estimated from the sur- vival rate in each year from 1976 to 1983 on the basis of current mortality rates according to age.

The denominator of the admission rates for the reference group was represented by the difference between the sum of the resident populations in the eight years under examination and the person-years of the cohort. SIR values were then calculated for the diseases considered and for all tumors. An indirect standardization according to age was used, with reference to incidence rates for each disease in the unlicensed population. The confidence intervals for the SIR values were calculated on the basis of a Poisson distribution (30).

The SIR values were calculated for the total cohort, for various age groups, and for groups of villages with the same kind of agricultural activity. The villages in question were identified with a cluster analysis performed on the 560 villages in the three provinces under study on the basis of the distribution of the proportion of farm land devoted to arable crops and woodland in each village.

\section{Results}

Table 1 shows the results for the quality control study conducted on each disease under investigation. The results of the study indicate that the records are far from reliable and that the extent of this unreliability varies according to the type of tumor.

Table 1. Results of the quality control checks.

\begin{tabular}{|c|c|c|c|c|c|c|}
\hline Malignant neoplasm ${ }^{a}$ & $\begin{array}{l}\text { Records } \\
\text { checked } \\
\text { (N) }\end{array}$ & $\begin{array}{l}\text { Correct } \\
\text { fourth } \\
\text { digitb }^{\text {b }} \\
\text { (N) }\end{array}$ & $\begin{array}{l}\text { Correct } \\
\text { third } \\
\text { digit }^{\text {b }} \\
\text { (N) }\end{array}$ & $\begin{array}{l}\text { Other } \\
\text { cancerc } \\
\text { (N) }\end{array}$ & $\begin{array}{l}\text { Non- } \\
\text { cancerc } \\
\text { (N) }\end{array}$ & $\begin{array}{c}\text { Error } \\
(\%)\end{array}$ \\
\hline Bone $(1700-1709)$ & 294 & 203 & 220 & 63 & 11 & 25.17 \\
\hline Connective and other soft tissue $(1710-1719)$ & 144 & 86 & 108 & 30 & 6 & 25.00 \\
\hline Melanoma of skin $(1720-1729)$ & 209 & 171 & 189 & 18 & 2 & 9.57 \\
\hline Other malignant neoplasm of skin $(1730-1739)$ & 581 & 468 & 553 & 24 & 4 & 4.82 \\
\hline Brain $(1910-1919)$ & 227 & 206 & 212 & 11 & 4 & 6.61 \\
\hline $\begin{array}{l}\text { Other and unspecified parts of the nervous system } \\
(1920-1929)\end{array}$ & 43 & 24 & 25 & 15 & 3 & 41.86 \\
\hline Lymphosarcoma and reticulosarcoma (2000-2008) & 190 & 147 & 166 & 21 & 3 & 12.63 \\
\hline Hodgkin's disease (2010-2019) & 357 & 302 & 304 & 49 & 4 & 14.85 \\
\hline $\begin{array}{l}\text { Other malignant neoplasm of lymphoid tissue } \\
(2020-2029)\end{array}$ & 357 & 183 & 215 & 133 & 9 & 39.78 \\
\hline Multiple myeloma (2030-2038) & 246 & 229 & 237 & 3 & 6 & 4.88 \\
\hline Lymphoid leukemia (2040-2049) & 292 & 233 & 259 & 30 & 3 & 11.30 \\
\hline Myeloid leukemia (2050-2059) & 176 & 126 & 145 & 29 & 2 & 18.18 \\
\hline Monocytic leukemia $(2060-2069)$ & 22 & 11 & 11 & 10 & 1 & 50.00 \\
\hline Other and unspecified leukemias $(2070-2078)$ & 93 & 51 & 65 & 19 & 9 & 30.11 \\
\hline Polycythemia vera $(2080-2089)$ & 40 & 38 & 38 & 1 & 1 & 5.00 \\
\hline Myelofibrosis $(2090-2099)$ & 36 & 28 & 28 & 3 & 5 & 22.22 \\
\hline Total & 3307 & 2500 & 2775 & 459 & 73 & 16.09 \\
\hline
\end{tabular}

a Code of the International Classification of Diseases (ICD), eighth revision, in parentheses.

b Of the ICD.

c Incorrectly diagnosed as the cancer in column 1. 
Table 2. Results of the quality control after aggregation by pathology.

\begin{tabular}{|c|c|c|c|c|c|}
\hline Site of malignant neoplasma & $\begin{array}{l}\text { Records } \\
\text { checked } \\
\text { (N) }\end{array}$ & $\begin{array}{l}\text { Correct } \\
\text { by } \\
\text { category } \\
(\mathrm{N})\end{array}$ & $\begin{array}{l}\text { Other } \\
\text { cancerb } \\
\text { (N) }\end{array}$ & $\begin{array}{l}\text { Non- } \\
\text { cancerb } \\
\text { (N) }\end{array}$ & $\begin{array}{c}\text { Error } \\
\text { by } \\
\text { category } \\
(\%)\end{array}$ \\
\hline $\begin{array}{l}\text { Skin }(1720-1739) \\
\text { Nervous system }(1910-1929) \\
\text { Lymphatic tissue }(2000-2029) \\
\text { Hematopoietic tissue }(2030-2099)\end{array}$ & $\begin{array}{l}790 \\
270 \\
904 \\
905\end{array}$ & $\begin{array}{l}768 \\
253 \\
870 \\
866\end{array}$ & $\begin{array}{l}16 \\
10 \\
18 \\
12\end{array}$ & $\begin{array}{r}6 \\
6 \\
16 \\
27\end{array}$ & $\begin{array}{l}2.79 \\
6.30 \\
3.76 \\
4.31\end{array}$ \\
\hline
\end{tabular}

a Code of the International Classification of Diseases, eighth revision, in parentheses.

b Incorrectly diagnosed as the cancer in column 1.

In table 2 the same results are grouped into tumor site classes. Bone and soft tissue tumors have not been considered due to the high error levels encountered ( 25.2 and $25.0 \%$, respectively). In contrast, in other tumor site groups (skin, central nervous system, lymphatic and hematopoietic tissues), the error level was low $(2.8-6.3 \%)$ and also uniformly distributed between the records of licensed and unlicensed patients. The degree of occupational risk was therefore calculated only for these diseases.

Table 3 shows the SIR values calculated for these diseases and reveals an SIR significantly greater than one for skin tumors and malignant lymphomas. In contrast, despite a slightly higher degree of risk, the SIR for tumors of the hematopoietic tissue was not significantly increased. With regard to tumors of the nervous system, the number of cases expected was slightly but not significantly higher than the number observed. The SIR for total tumors was significantly lower than one.

The SIR values were also divided into birth groups (births after 1934; between 1914 and 1933 and before 1913) (table 4). Although statistical significance was found only for skin and nervous system tumors among the older subjects, for all tumors but lymphomas the risk tended to increase with age.

Table 5 shows the SIR values for the license-holders in the three clusters of villages grouped according to agricultural activity. In cluster I, where $92.4 \%$ of the agricultural land is devoted to arable farming, the figures revealed a high risk for malignant lymphomas (SIR 1.8, P<0.01). In cluster II, where $68.8 \%$ of the land is devoted to woodland, only skin tumors had an SIR significantly greater than one (SIR $1.7, \mathrm{P}<0.05$ ), though it should be pointed out that the number of person-years was much smaller than in the other two clusters. For this reason, the increased risk of tumors of the nervous system (SIR 1.6) and hematopoietic tissue (SIR 1.6) could be of relevance. We also observed that the SIR for lymphomas was less than one. Finally, in cluster III, where land is devoted to mixed farming (58.0\% arable, $42.0 \%$ woodland), all the SIR values fell between those of the other two clusters.

\section{Discussion}

The objective of this study was to discover whether the incidence of certain malignant tumors was higher among pesticide users than among a reference population in an intensively agricultural area. We therefore examined the first hospital admissions of the men living in three provinces of south Piedmont and authorized to buy and use pesticides in Italy's toxicologic classes I and II. We compared our findings with those on the entire male population residing in the same area but not authorized to use pesticides.

The first limitation of our study stems from the exposure criterion adopted (possession or not of a license to buy and use pesticides), which inevitably resulted in the misclassification of those who were effectively exposed to potentially carcinogenic pesticides despite their not being license holders. The license authorizes holders to buy and use pesticides known to be highly toxic (on the basis of their median lethal dose), whereas our interest was in the carcinogenicity of the pesticides. In fact, the question is irrelevant as far as the potential misclassification of exposure among the cohort under study was concerned. Sampling conducted on the farmers in the area under study revealed that those authorized to buy and use pesticides in classes I and II also employed other products for which no license is required (31). At the same time, a proportion of the reference group considered not exposed in our research was actually occupationally exposed to potentially carcinogenic products that do not require a license, due to their low acute toxicity.

Given the causal association between exposure and tumor onset, the bias described has led us to underestimate the degree of risk (SIR), since the design of our research involved a comparison between a group of the occupationally exposed persons and a population of which at least part, though possibly only a small part, was in some danger of occupational exposure.

The second potential limitation is related to the information source employed in our search for tumor cases among the pesticide license-holders and the reference group. Our quality control study showed that coding errors were irrelevant and in any event uniformly distributed between the subjects "exposed" and those "not exposed." However, we estimated the errors due only to false positives (patients admitted to the hospital with noncancerous diseases or tumors at sites not considered in this study, but wrongly coded as a study site tumor). We did not consider false negatives (patients admitted to the hospital with a tumor at one of 
the study sites wrongly coded as a tumor at another site or a noncancerous disease). Though we may assume such errors to be evenly distributed between the two groups compared, any interpretation of the results must necessarily take into account this potential source of bias - since the incidence of the diseases considered is already low, the omission of only a few cases could significantly alter incidence rates that are already unstable.

Another problem arising from the source of information used is that the discharge file covered the whole of Piedmont but did not include admissions to hospitals outside this region. In this context, an investigation was conducted in a cancer hospital of a nearby region that attracts most Piedmont residents. It was found that not only was admission to this hospital always preceded by a period in a Piedmontese hospital, but also that the proportion of emigrations outside our region was evenly distributed between the subjects "exposed" and those "not exposed." In this instance the check on a single hospital outside the region offered no guarantee that some cases had not been missed.

The number of tumor cases encountered in the cohort of our study was significantly lower than expected. This finding confirms reports in the literature $(1,32)$ and has been attributed to a lower incidence of smokers (3) and the healthier environment enjoyed by rural dwellers (32). In this context, the sample survey that we mentioned earlier (31) showed a lower incidence of smoking $(40 \%)$ than that found among industrial workers in the same area $(60 \%)$. While we accept that part of the low tumor incidence is attributable to these factors, it is also possible that the low incidence of tumors among the subjects exposed to the pesticides in question is due to the "healthy worker effect," a term used to indicate a series of situations that, as a result of the cohort selection process, leads researchers to underestimate occupational risk. In this specific case, our selection of the cohort was influenced by the fact that the subjects selected had actively requested authorization to buy and use pesticides so that, at least when they presented the request, none of them was suffering from clinically evident cancer. In contrast, during the years in which the cohort was recruited, a certain number of referents had tumors. As a result, due to the short duration of follow-up, the number of prevalent cases recorded is likely to have been higher among the reference group than among the exposed group, especially for diseases with a longer life expectancy. This source of bias also leads to an underestimation of the degree of risk.

The higher incidence of skin tumors might be indicative of exposure to ultraviolet rays typical of farm workers (1). Though this finding does not allow us to hypothesize a chemical etiology for the diseases in question, it does confirm the validity of our research design and the adequate size of our sample.

The higher incidences of nervous and hematopoietic tissue tumors, though not significantly increased for the cohort as a whole, did reveal a clear-cut age-related trend and a greater risk in villages primarily devoted

Table 3. Standardized incidence ratios (SIR) for the overall cohort. ( $95 \% \mathrm{Cl}=95 \%$ confidence interval)

\begin{tabular}{lrrrr}
\hline Malignant neoplasm & \multicolumn{1}{c}{ Observed Expected } & SIR & $95 \% \mathrm{CI}$ \\
\hline All malignant neoplasms & 631 & 877.81 & 0.7 & $0.6-0.8$ \\
Skin & 58 & 41.29 & 1.4 & $1.0-1.8$ \\
Nervous system & 25 & 25.62 & 1.0 & $0.6-1.4$ \\
Lymphatic tissue & 45 & 31.79 & 1.4 & $1.0-1.9$ \\
Hematopoietic tissue & 49 & 43.01 & 1.1 & $0.8-1.5$ \\
\hline
\end{tabular}

Table 4. Standardized incidence ratios (SIR) by birth cohorts. (95\% Cl=95\% confidence interval)

\begin{tabular}{|c|c|c|c|c|c|c|c|c|c|}
\hline \multirow{3}{*}{ Malignant neoplasm } & \multicolumn{9}{|c|}{ Birth cohorts } \\
\hline & \multicolumn{3}{|c|}{1934 and later } & \multicolumn{3}{|c|}{$1933-1914$} & \multicolumn{3}{|c|}{1913 and earlier } \\
\hline & $\begin{array}{l}\text { Ob- } \\
\text { served }\end{array}$ & SIR & $95 \% \mathrm{Cl}$ & $\begin{array}{l}\text { Ob- } \\
\text { served }\end{array}$ & SIR & $95 \% \mathrm{Cl}$ & $\begin{array}{l}\text { Ob- } \\
\text { served }\end{array}$ & SIR & $95 \% \mathrm{Cl}$ \\
\hline Skin & 5 & 1.1 & $0.4-2.6$ & 29 & 1.3 & $0.9-1.9$ & 24 & 1.6 & $1.0-2.4$ \\
\hline Nervous system & 2 & 0.4 & $0.0-1.4$ & 14 & 0.9 & $0.5-1.4$ & 9 & 2.1 & $1.0-4.0$ \\
\hline Lympnatic tissue & 10 & 1.6 & $0.8-2.9$ & 24 & 1.3 & $0.8-1.9$ & 11 & 1.5 & $0.8-2.7$ \\
\hline Hematopoietic tissue & 2 & 0.4 & $0.1-1.6$ & 23 & 1.0 & $0.6-1.5$ & 24 & 1.6 & $0.9-2.2$ \\
\hline
\end{tabular}

Table 5. Standardized incidence ratios (SIR) by cluster of villages with homogeneous main crop. (95\% Cl=95 $\%$ confidence interval)

\begin{tabular}{|c|c|c|c|c|c|c|c|c|c|}
\hline \multirow[b]{2}{*}{ Malignant neoplasm } & \multicolumn{3}{|c|}{ First cluster (arable land) } & \multicolumn{3}{|c|}{ Second cluster (woodiand) } & \multicolumn{3}{|c|}{ Third cluster (mixed) } \\
\hline & $\begin{array}{l}\text { Ob- } \\
\text { served }\end{array}$ & SIR & $95 \% \mathrm{Cl}$ & $\begin{array}{c}\text { Ob- } \\
\text { served }\end{array}$ & SIR & $95 \% \mathrm{Cl}$ & $\begin{array}{l}\text { Ob- } \\
\text { served }\end{array}$ & SIR & $95 \% \mathrm{Cl}$ \\
\hline $\begin{array}{l}\text { Skin } \\
\text { Nervous system } \\
\text { Lymphatic tissue } \\
\text { Hematopoietic tissue }\end{array}$ & $\begin{array}{l}22 \\
10 \\
31 \\
24\end{array}$ & $\begin{array}{l}1.0 \\
0.7 \\
1.8 \\
1.0\end{array}$ & $\begin{array}{l}0.7-1.6 \\
0.3-1.3 \\
1.2-2.5 \\
0.7-1.7\end{array}$ & $\begin{array}{r}14 \\
5 \\
4 \\
8\end{array}$ & $\begin{array}{l}1.7 \\
1.6 \\
0.9 \\
1.6\end{array}$ & $\begin{array}{l}1.0-2.9 \\
0.5-3.8 \\
0.3-2.3 \\
0.7-3.1\end{array}$ & $\begin{array}{l}22 \\
10 \\
10 \\
16\end{array}$ & $\begin{array}{l}1.7 \\
1.6 \\
1.0 \\
1.3\end{array}$ & $\begin{array}{l}1.1-2.6 \\
0.8-2.9 \\
0.5-1.9 \\
0.8-2.1\end{array}$ \\
\hline Person-years & \multicolumn{3}{|c|}{99284} & \multicolumn{3}{|c|}{29159} & \multicolumn{3}{|c|}{55393} \\
\hline
\end{tabular}


to woodland crops. These findings may be related to the widespread use of chlororganic insecticides in the area under study up to the early $1970 \mathrm{~s}(3,5-7,10,19)$.

Malignant lymphomas showed an SIR significantly higher than one for the total cohort. There are at least two reasons for believing that this finding may be attributable to exposure to chlorophenoxyacetic herbicides, as it has been suggested by many authors (13-17). First, the higher incidence was only found in predominantly arable areas, where greater use is made of herbicides. Second, the use of chlorophenoxyacid products has increased in recent years. Data available in the three provinces under study show that annual consumption rose from $73659 \mathrm{~kg}$ in 1965 to $125495 \mathrm{~kg}$ in 1978 . In line with this hypothesis, the absence of an age-related SIR trend suggests that the quantitatively different exposures in the age ranges considered make up for a higher risk among the younger subjects.

Our results do not allow us to reject the hypothesis of an association between occupational exposure to pesticides and the onset of certain tumors. Indeed, they seem to support it, especially in view of their similarity to reports in the literature (external consistency) and their being justified and explained by the geographic and age distribution (internal consistency). Nevertheless, the potential sources of bias described suggest that we should be extremely cautious in interpreting the results of this study. They will only be validated by the monitoring of mortality in the cohort of pesticide users, and this procedure would thus solve the problems raised by the case source employed.

If the results of such a study confirm our present findings, we will carry out a case-referent study on our cohort in order to identify the nature and degree of the association shown in the present study.

\section{References}

1. Blair A, Malker H, Cantor KP, Burmeister LF, Wiklund K. Cancer among farmers: a review. Scand J Work Environ Health 1985;11:397-407.

2. Burmeister LF, Everett GD, VanLier IP. Selected cancer mortality and farm practices in Iowa. Am J Epidemiol 1983;118:72-7.

3. Cantor KP, Blair A. Farming and mortality from multiple myeloma: a case-control study with the use of death certificates. J Natl Cancer Inst 1984;72:231-55.

4. Gallanger RP, Spinelli J, Elwood JM, Skippen DH. AIlergies and agricultural exposure as risk factors for multiple myeloma. Br J Cancer 1983;48:853-7.

5. Gallangher RP, Threfall WJ, Jeffries E, Band PR, Spinelli J, Coldman J. Cancer and aplastic anemia in British Columbia farmers. J Natl Cancer Inst 1984;72: 1311-5.

6. Morris PD, Koepsell TD, Daling JR, et al. Toxic substance exposure and multiple myeloma: a case-control study. J Natl Cancer Inst 1986;76:987-94.

7. Nandakumar A, Armstrong BK, DeKlerk NH. Multiple myeloma in Western Australia: a case-control study in relation to occupation, father's occupation, socioeconomic status and country of birth. Int J Cancer 1986; $37: 223-6$.

8. Pearce NE, Smith AH, Fisher DO. Malignant lympho- ma and multiple myeloma linked with agricultural occupations in a New Zealand cancer registry-based study. Am J Epidemiol 1985;121:225-37.

9. Saftlas AF, Blair A, Cantor KP, Hanrahan L, Anderson A. Cancer and other causes of death among Wisconsin farmers. Am J Ind Med 1987;11:119-29.

10. Steineck G, Wiklund K. Multiple myeloma in Swedish agricultural workers. Int J Epidemiol 1986;15:321 - 5.

11. Stubbs HA, Harris J, Spear RC. A proportionate mortality analysis of California agricultural workers, 19781979. Am J Ind Med 1984;6:305-20.

12. Thomas TL, Krekel S, Heid M. Proportionate mortality among male corn wet-milling workers. Int J Epidemiol 1985;14:432-7.

13. Eriksson ML, Hardell P, Berg NO, Moller T, Axelson $O$. Soft-tissue sarcomas and exposure to chemical substances: a case-referent study. $\mathrm{Br} \mathrm{J}$ Ind Med 1981;38: 27-33.

14. Hardell L, Eriksson M, Lenner P, Lundgren E. Malignant lymphoma and exposure to chemicals expecially organic solvents, chlorophenols and phenoxyacids: a casecontrol study. Br J Cancer 1981;43:169-176.

15. Hardell L, Sandstrom A. Case-control study: soft-tissue sarcomas and exposure to phenoxyacetic acids or chlorophenols. Br J Cancer 1979;39:711-7.

16. Smith AM, Pearce NE, Fisher DO, Giles HJ, Teague CA, Howard JK. Soft-tissue sarcoma and exposure to phenoxyherbicides and chlorophenols in New Zealand. J Natl Cancer Inst 1984;73(5):111-7.

17. Vineis P, Terracini B, Ciccone G, et al. Phenoxy herbicides and soft-tissue sarcomas in female rice weeders: a population-based case-referent study. Scand J Work Environ Health 1987;13:9-17.

18. International Agency for Research on Cancer. Cancer epidemiology of pesticides manifacturers, formulators and users. Lyon: International Agency for Research on Cancer, 1983:37-56. (IARC monographs on the evaluation of the carcinogenic risk of chemicals to humans; vol 30.)

19. Infante PF, Epstein SS, Newton WA Jr. Blood dyscrasias and childhood tumors and exposure to chlordane and heptachlor. Scand J Work Environ Health 1978;4: $137-50$.

20. Wang HH, Grufferman S. Aplastic anemia and occupational pesticide exposure: a case-control study. J Occup Med 1981;23(5):364-6.

21. Kabat GC, Dieck GS, Wynder EL. Bladder cancer in nonsmokers. Cancer 1986;57:362-7.

22. Delzell E, Grufferman S. Mortality among white and nonwhite farmers in North Carolina. Am J Epidemiol 1985;121:391-402.

23. Donna A, Betta PG, Robutti F, Crosignani P, Berrino $\mathrm{F}$, Bellingeri D. Ovarion mesothelial tumors and herbicides: a case-control study. Carcinogenesis 1984;7: 941-2.

24. Blair A, Grauman JD, Lubin HJ, Fraumeni JF. Lung cancer and other causes of death among licensed pesticide applicators. J Natl Cancer Inst 1983;71:31-7.

25. Barthel E. Increased risk of lung cancer in pesticide-exposed male agricultural workers. J Toxicol Environ Health 1981;8:1027-40.

26. Ditraglia D, Brown DP, Namekata T, Iverson N. Mortality study of workers employed at organochlorine pesticide manufacturing plants. Scand $J$ Work Environ Health 1981;7 (suppl 4):140-6.

27. Hoar SK, Blair A, Holmes FF, et al. Agricultural herbicide use and risk of lymphoma and soft-tissue sarcoma. JAMA 1986;256:1141-7.

28. Wang HH, MacMahon B. Mortality of pesticide applicators. J Occup Med 1979;21:741-4.

29. Calleri M, Corrao G, Gilli G. Esposizione a prodotti fitoiatrici ed incidenza di patologie tumorali maligne: risultati di uno studio di coorte. In: Zatta P, ed. I fitoiatrici in agricoltura Scelte strategiche per una agricol- 
tura ambientale. Padova: Aldo Francisci, 1986:70-82.

30. Bailar JC, Ederer F. Significance factors for the ratio of a Poisson variable to its expectation. Biometrics 1964;20:639-43.

31. Bosia S, Piccioni P. Indagine sull'utilizzo di pesticidi in un campione di aziende vitivinicole della provincia di Asti: considerazioni preliminari sullo stato di salute degli utilizzatori. In: Produzione frutticola: protezione dell'ambiente e tutela della salute. Saluzzo: ICAP, 1985: 87-112.

32. Wiklund K, Holm LE. Soft tissue sarcoma risk in Swedish agricultural and forestry workers. J Natl Cancer Inst 1986;76:229-34.

Received for publication: 15 December 1987 